\title{
Live weight and body condition changes in dry cows at pasture and effects on subsequent performance ${ }^{1,2}$
}

\author{
Paul F. Randel ${ }^{3}$ \\ J. Agric. Univ. P.R. 84(3-4):165-180 (2000)
}

\begin{abstract}
During a 720-d experiment in a Holstein and Brown Swiss herd, two feeding regimens were compared during the grazing phase of dry cow management until confinement before expected calving. The two treatments involved rotational grazing (24-d cycles) at a stocking rate of 2.5 animals per hectare in: (A) all-grass swards or (B) all-grass plus $3 \mathrm{~h}$ daily access to swards of Leucaena leucocephala and grasses. Large heifers were added as needed to maintain constant group size at pasture. A daily supplement of $2 \mathrm{~kg} / \mathrm{head}$ of bulky concentrate was fed. During the first 19 mo of the study, while rainfall was adequate, dry cows in treatments $A$ and $B$ gained live weight (LW) satisfactorily $(0.69 \pm 0.26$ and $0.67 \pm 0.23 \mathrm{~kg} / \mathrm{d})$ and increased in body condition score (BCS) on a scale of 1 to 5 at rates of 0.40 and 0.34 point/100 d, respectively. During the final 5 mo, pasture conditions and $L W$ gains were poor because of prolonged drought. Monthly rainfall of $50 \mathrm{~mm}$ or more maintained grazing conditions adequate for use with the present level of supplemental feeding. There were no differences $(P>0.05)$ between treatments. Under common postpartum management, standard 305-d lactational milk yields were unaffected by previous treatments $A$ or $B$. However, a positive trend $(P<0.10)$ was associated with higher prepartum BCS. Cows that scored $<3.0,3.0,3.25$, 3.5 and $>3.5$ produced 4,$013 ; 4,111 ; 4,367 ; 4,627$ and $4,450 \mathrm{~kg}$, respectively. Postcalving reproductive performance was not affected by previous treatment or by BCS prepartum or BCS at 6 wk postpartum.
\end{abstract}

Key words: dry cows, grazing, supplementation, body condition, milk production

\section{RESUMEN}

Cambios en el peso vivo y condición corporal de vacas secas a pastoreo y su efecto sobre el desempeño productivo subsecuente

Durante un experimento de $720 \mathrm{~d}$, realizado en un hato de las razas Holstein y Pardo Suizo, se comparó dos regímenes alimenticios durante la fase a pastoreo del manejo de vacas secas, hasta cambiar a confinamiento anticipando el parto. Los dos tratamientos involucraron pastoreo rotativo (ciclos de 24 d) a una carga animal de 2.5/ha, en predios (A) de gramineas solamente o (B) de éstas más acceso diario por $3 \mathrm{~h}$ a predios de Leucaena

'Manuscript submitted to Editorial Board 10 February 1999.

2The author acknowledges the contribution of Carlos Goytia in gathering data on subsequent performance of the experimental cows.

${ }^{3}$ Researcher, Animal Industry Department, University of Puerto Rico-Mayagüez, P.O. Box 9030, Mayagüez, PR 00680-9030. 


\begin{abstract}
leucocephala y gramineas. Se usaron novillas grandes en la proporción requerida para mantener constante el tamaño de los grupos en pasto. Se dio una suplementación diaria de $2 \mathrm{~kg} / \mathrm{animal}$ de concentrado voluminoso. Durante los primeros 19 meses de experimentación, mientras la lluvia fue adecuada, las vacas secas en los tratamientos A y B ganaron peso vivo (PV) satisfactoriamente $(0.69 \pm 0.26$ y $0.67 \pm 0.23 \mathrm{~kg} / \mathrm{d})$ y aumentaron en condición corporal estimada (CCE) en una escala de 1 a 5 , a razón de 0.40 y 0.34 punto/100 d, respectivamente. Durante los últimos cinco meses las condiciones de los pastos y la ganancia en PV fueron pobres debido a una sequia prolongada. Una precipitación pluvial mensual de $50 \mathrm{~mm}$ o mayor bastó para mantener condiciones de pastoreo adecuadas para uso en combinación con el presente nivel del suplementación. No se detectaron diferencias $(P>0.05)$ entre los tratamientos. Bajo manejo común postparto, la producción de leche por lactancia de $305 \mathrm{~d}$ no fue afectada por los tratamientos previos $A$ y $B$, pero hubo una tendencia positiva $(P<0.10)$ asociada a mayor CCE preparto. Las vacas con puntuaciones de $<3.0,3.0,3.25,3.5 \mathrm{y}$ $>3.5$ produjeron 4,$013 ; 4,111 ; 4,367 ; 4,627$ y $4,450 \mathrm{~kg}$, respectivamente. El desempeño reproductivo postparto no fue afectado por los tratamientos previos ni por la CCE preparto o a las seis semanas postparto.
\end{abstract}

\title{
INTRODUCTION
}

Feeding and management of dry cows constitutes an important component of dairy farm operations. Adequate attention to these animals is essential to ensure good performance in the next lactation. In countries with high levels of milk production per cow, obtained by very intensive feeding, dairy cows commonly replenish their body reserves in mid and late lactation. Thus, Gearhart et al. (1990) recommend that the body condition score (BCS) at drying off should be the same as that desired at calving. A serious management concern under these conditions is to avoid overfattening during the dry period, since this may increase metabolic disorders in early lactation (Frank et al., 1980). By contrast, in countries such as Puerto Rico, where production per cow and levels of feeding are generally not so high, a large proportion of the dairy cows need the dry period to restore body reserves. To support the positive energy balance required during this period, intakes considerably above maintenance are necessary. However, to optimize economic results, the feeding of dry cows must be relatively inexpensive, since at this stage they do not generate income. Commonly, dry cow feeding depends on grazing and conserved forages as the principal dietary sources.

On the south coast of the island, where long periods of low rainfall are common, the use of restricted grazing in paddocks of deep-rooted leguminous plants, such as leucaena, can improve long term animal performance (Mejía et al., 1993). Therefore, one of the objectives of this study was to compare two feeding regimens for dry cows, both based on grazing at the same stocking rate and a moderate supplementation with concentrates; one employed swards of grasses only, while the other included $3 \mathrm{~h}$ of daily access to leucaena. Also of interest was the trend 
in time of subjectively evaluated pasture condition and its relation to rainfall and animal performance.

A second objective was to observe changes occurring in the body reserves of the animals, as reflected in live weight (LW) and estimated body condition, during the dry period and until $6 \mathrm{wk}$ postpartum, and to determine the influence of these changes on lactational milk yield and reproductive performance.

\section{MATERLALS AND METHODS}

All dry cows of the Lajas Substation dairy herd were included in the experiment, except a few that were unfit physically or had already been designated for culling. Some cows participated only briefly in the grazing phase, while others (those still being inseminated or those in early gestation upon starting) participated over long periods. It was deemed that LW and BCS data from the former would be unreliable because of weighing and scoring errors over short intervals; and data from the latter would not be representative of animals replenishing body reserves in dry periods of normal length. Therefore, data from both extremes were excluded from the comparison between treatments (Table 1); data used were from dry cows that participated for at least two complete grazing cycles ( $48 \mathrm{~d}$ ). The data did not include observations beyond participation in six cycles (144 d).

In addition to the dry cows, a sufficient number of the oldest heifers of the herd were included to maintain constant size of the groups at pasture. These were mostly pregnant, aged $2 \mathrm{yr}$ or older, and of initial LW exceeding $400 \mathrm{~kg}$. Some heifers participated in the experiment during one continuous period, whereas other's were put on and taken off experimentation two or more times as needed or not to complete the two groups, depending on the varying number of dry cows. The 170 animals that participated represented three breeds. The great majority $(86.5 \%)$ were grade or purebred Holsteins, $10.0 \%$ were Brown Swiss, and $3.5 \%$ were $\mathrm{F}_{1}$ crosses of these two breeds. Assignment of the animals to treatment group did not take breed into account. At the outset of the experiment in July 1992, 24 dry cows and 14 heifers formed two nearly balanced groups of 15 and 23 animals each. Thereafter, all cows at drying off, with expectation of another calving in the herd, were incorporated into the two groups at random.

The two experimental treatments were applied during the gxazing phase, which was planned to last until 3 wk prior to the expected calving date and to be followed by a precalving phase in confinement. Two characteristics differentiated the treatments. Firstly, in treatment A the animals grazed only swards of mixed grasses; in B, they had limited 
TABLE 1.-Mean body weight and condition responses of dry cows during not less than 48 nor more than 14 days of grazing phase during the first 19 months and last five months of experimentation.

\begin{tabular}{|c|c|c|c|c|}
\hline & \multicolumn{2}{|c|}{ Treatment A } & \multicolumn{2}{|c|}{ Treatment $B$} \\
\hline & $\begin{array}{l}\text { First } 19 \\
\text { months }\end{array}$ & $\begin{array}{l}\text { Last } 5 \\
\text { months }\end{array}$ & $\begin{array}{l}\text { First } 19 \\
\text { months }\end{array}$ & $\begin{array}{l}\text { Last } 5 \\
\text { months }\end{array}$ \\
\hline \multicolumn{5}{|l|}{ Live weight } \\
\hline Number of animals & 45 & 14 & 53 & 18 \\
\hline Days of observation & 108 & 95 & 103 & 104 \\
\hline Initial weight (kg) & $575 \pm 64^{1}$ & 575 . $: 60$ & $594 \pm 66$ & $558 \pm 100$ \\
\hline Final weight (kg) & $647 \pm 7 \lambda$ & 605.48 & $659 \pm 68$ & $569 \pm 80$ \\
\hline Total gain $(\mathrm{kg})$ & $72 \pm 31$ & $30 \pm 26$ & $65 \pm 29$ & $10 \pm 35$ \\
\hline Daily gain (kg) & $0.69 \pm 0.26$ & $0.30 \pm 0.28$ & $0.67 \pm 0.23$ & $0.05 \pm 0.47$ \\
\hline \multicolumn{5}{|l|}{ Body condition score $(1-5)^{2}$} \\
\hline Number of animals & 42 & 14 & 49 & 16 \\
\hline Days of observation & 104 & 88 & 94 & 101 \\
\hline Initial score & $3.03 \pm 0.50$ & $3.02 \pm 0.49$ & $3.11 \pm 0.37$ & $3.08 \pm 0.67$ \\
\hline Final score & $3.45 \pm 0.32$ & $3.29 \pm 0.34$ & $3.45 \pm 0.29$ & $3.22 \pm 0.63$ \\
\hline Total increase in score & $0.42 \pm 0.40$ & $0.27 \pm 0.39$ & $0.35 \pm 0.36$ & $0.14 \pm 0.24$ \\
\hline Equivalent increase/100 d & 0.40 & 0.31 & 0.34 & 0.12 \\
\hline
\end{tabular}

${ }^{1}$ Standard deviation.

${ }^{2} \mathrm{BCS}$ : 1 = very lean; 2 = lean; 3 = medium; 4 = overconditioned; $5=$ obese.

daily access to an area where leucaena was available. Secondly, the bulky concentrates fed in $\mathrm{A}$ and $\mathrm{B}$ were formulated to contain 15 and $12.5 \%$ crude protein $(\mathrm{CP})$ on the dry basis, respectively. The rationale for this difference was that the animals in $\mathrm{B}$ should obtain more CP from grazing than those in $\mathrm{A}$.

Initially treatment $\mathrm{A}$ employed six paddocks of 1 ha each and 15 grazing animals (2.5/ha). After the first eight 24-d grazing cycles, two additional paddocks, of 1.0 and 1.12 ha, were added to this pasture area. Thereafter, 20 animals grazed eight paddocks, totaling 8.12 ha $(2.46 / \mathrm{ha})$. The gramineous forages present were predominantly stargrass (Cynodon nlemfuensis) and pajón (Dichantium annulatum), with smaller amounts of several other species. Treatment B used four paddocks of unequal size, totaling 9.16 ha in which 23 animals grazed (2.51/ha). Each of the four was divided into a larger area with all-grass swards (mostly the above mentioned species) and a smaller area with leucaena bushes in rows and associated grasses, including some guinea (Panicum maximum). The larger areas constituted $72 \%$ and the smaller areas $28 \%$ of the total. 
Animal biomass (stocking weight) per unit of pasture area varied little over the course of the experiment. Means per grazing cycle were 1,436 \pm 94 and $1,493 \pm 76 \mathrm{~kg} / \mathrm{ha}$ in treatments $\mathrm{A}$ and B, respectively. Mean LW of $A$ and $B$ dry cows and heifers at pasture was 615 and $629 \mathrm{~kg}$ and 473 and $499 \mathrm{~kg}$, respectively. Small amounts of N-P-K inorganic fertilizer (18, 6 and $12 \mathrm{~kg} / \mathrm{ha}$, respectively) were applied to the all-grass areas during the early months of experimentation, but thereafter no further applications were made. All told, fertilization was a minor factor in pasture management in this study. A daily forage condition score (FCS), based on a subjective assessment of the forage available in each area being grazed, was made on a scale from 1 to 10 . As a rough guideline based on experience, a pasture of score 7 was conceived as adequate to permit acceptable animal performance from grazing without supplementation (except possibly minerals), whereas scores of 6,5 and 4 would require light, moderate, and heavy encigy supplementation, respectively, to achieve this result. No FCS values were recorded higher than 8 , nor lower than 4 , except during the final three grazing cycles, under conditions of severe drought. The great majority of scores were within the range of 5 to 7 .

The daily management routine (with mean times) was as follows: at 05:09 $\pm 0.03 \mathrm{~h}$ group B was moved from the larger to the smaller area within its paddock, where it remained for $3.00 \pm 0.02 \mathrm{~h}$ until 08:09 \pm $0.3 \mathrm{~h}$. At 07:05 h group A was moved to the stable for feeding. Group B followed about $1 \mathrm{~h}$ later. After consuming their supplements all the animals remained in a large unpaved yard, where drinking water and shade were available. Both groups returned to their respective paddocks at 12:16 h. Thus, group A spent about $183 / 4$ and $51 / 4 \mathrm{~h}$ on and off pasture, respectively, during each 24-h cycle; group $B$ spent about $1 \mathrm{~h}$ less $(4 \mathrm{~h}$ ) off pasture, $17 \mathrm{~h}$ in an all-grass area, and $3 \mathrm{~h}$ with access to leucaena.

The bulky concentrates were fed in a line of stanchions. Before the animals entered the stable, the total amount of supplement was distributed in approximately equal portions placed in the manger in front of the number of stanchions needed to accommodate the group. Once inside, the animals were free to enter and exit the stanchions at will. This labor-saving method achieved conditions approaching individual feeding of equal amounts of supplement per head. The planned allowance of $2 \mathrm{~kg}$ daily was in effect until mid-March 1994. Thereafter, during two intervals totaling 91 days, until the experiment ended, the daily offering was increased to $2.5 \mathrm{~kg}$, in an attempt to partially compensate for the pasture shortage. Over the 720-day experiment the mean allowance of supplemental feed was $2.06 \mathrm{~kg}$ daily.

The formulas of the two supplements included equal proportions of both ground maize and wheat middlings $(33.08 \%$ of each in $\mathrm{A}$ and $38.3 \%$ in B, as mixed). They had in common $15 \%$ of ground grass hay, 
$6 \%$ of cane molasses, $1.0 \%$ of salt, and $0.45 \%$ of phosphate supplement; but A contained $10.89 \%$ of soybean meal and $0.5 \%$ of urea, whereas $\mathrm{B}$ included $0.95 \%$ of urea as the sole high CP ingredient. A sample was taken from every batch (usually 0.5 or $1 \mathrm{t}$ per mixing) of the supplemental feeds and the dry matter (DM) content determined by oven drying $\left(65^{\circ} \mathrm{C} / 48 \mathrm{~h}\right)$. Dried samples accumulated over several months were composited. Eight composite samples of each feed were analyzed for ash $\left(550^{\circ} \mathrm{C} / 6 \mathrm{~h}\right)$ and $\mathrm{CP}$ (micro-Kjeldahl method). The first three composites of each feed were also analyzed for acid detergent fiber (ADF) (Goering and Van Soest, 1970). The analytical results showed concentrate A to be only $1.1 \%$ higher than B in CP content of the DM (15.4 vs. $14.3 \%$ ) rather than $2.5 \%$ higher, as planned. Supplement B was higher in ADF content ( 16.0 vs. $14.4 \%$ ), but slightly lower in DM and ash contents ( 87.5 vs. $87.2 \%$ and 6.6 vs. $6.2 \%$ ) than supplement A.

The experimental protocol specified placing the animals in an unpaved confinement area $3 \mathrm{wk}$ prior to expected calving. However, in some cases the expected date had a wide margin or error. Dry cows assigned to treatment A spent a mean of $14.6 \mathrm{~d}$ (range 1 to $60 \mathrm{~d}$ ) in precalving confinement; corresponding figures for $\mathrm{B}$ were $16.3 \mathrm{~d}$ ( 1 to $58 \mathrm{~d}$ ). In confinement the diet consisted of $5 \mathrm{~kg}$ daily of bulky concentrate $\mathrm{A}$, group-fed once daily in a feed bunk, and an ad libitum offering of either grass hay or chopped fresh grass. After calving, all animals were subjected to standard herd management for lactating cows. This included heavy feeding of a concentrate mixture (including some ground hay) in two daily portions. Fresh chopped forage, mostly star, pajón and Johnson (Sorghum halapense) grasses or grass hay was group-fed in a large lot. Occasionally the herd grazed heterogeneous gramineous swards.

Upon commencing the experiment and at the end of each grazing cycle $\pm 1 \mathrm{~d}$, all experimental dry cows and heifers at pasture and in precalving confinement were weighed and body condition was scored on a single day beginning at about 07:00 $\mathrm{h}$. The BCS procedure of Wildman et al. (1982), as explained and illustrated by Sniffen and Ferguson (1991), was used. However, many animals had to be scored rapidly; thus, visual estimation was relied on, with little or no palpation. Individual weighings took place when an animal began the grazing phase or was transferred to precalving confinement. Within $24 \mathrm{~h}$ of calving the animals were weighed, but not condition scored. They were weighed again and scored at 6 wk postpartum, the point at which weight and score were expected to coincide with the minimum LW and BCS values during lactation (NCR, 1988). Milk production and composition (fat, protein) were obtained from the Dairy Herd Improvement Program.

For statistical analysis the data from the grazing phase were sorted by two periods, those from the first 19 mo of experimentation, when 
pasture conditions permitted satisfactory animal performance; and those of the final $5 \mathrm{mo}$, when grazing conditions and animal responses were poor. Comparisons between treatments were made by unpaired ttest and chi-square, as appropriate for dependent variables of the continuous and enumeration type, respectively. The effects of prepartum $\mathrm{BCS}$ on milk production and reproductive performance were examined by means of a one-factor analysis of variance (Snedecor, 1956).

\section{RESULTS AND DISCUSSION}

The rainfall curve from July 1992 to July 1994, shown in Figure 1, represents a 2 -mo rolling mean, based on the present month and the previous one. The long-term precipitation pattern in Lajas is characterized by two annual rainy seasons, a short one in May and a longer one from August to October. The short rainy season of 1992 preceded the start of the experiment by about 2 mo. The usual precipitation pattern was evident during the latter half of 1992 and in 1993, but in 1994 the expected short rainy season failed to occur. Thus, approximately the last 5 mo of the experiment coincided with a prolonged drought. Mean FCS per grazing cycle of the three groupings of pastures (those of treat-

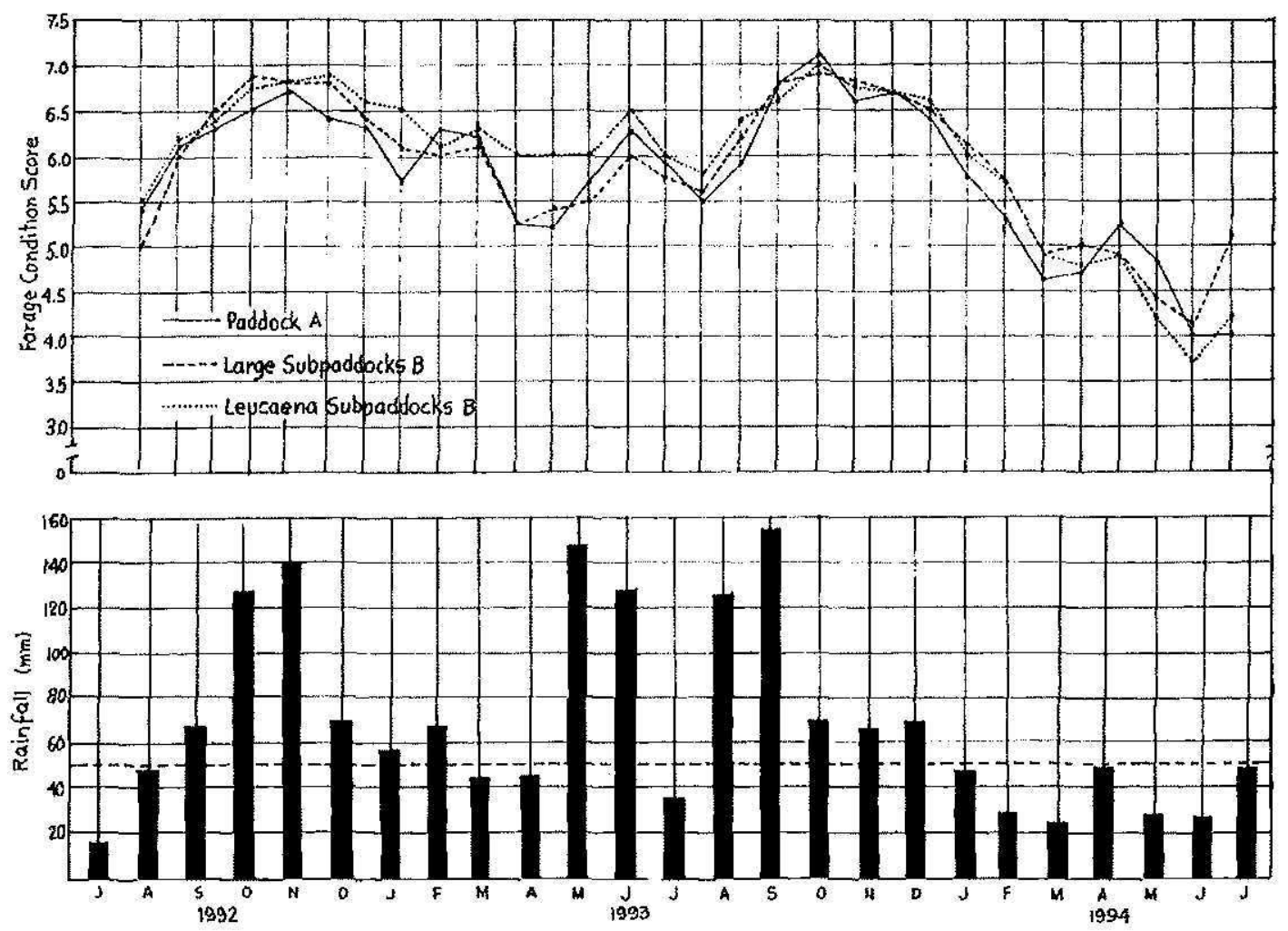

FIGURE 1. Mean forage condition scores per grazing cycle (above) and two-month rolling means of rainfall (below) during the experiment. 
ment A; all-grass areas, and leucaena grass areas of B) declined at this time to levels mostly lower than 5.0, and even below 4.5 (Figure 1). An attempt was made to apply gravity-flow irrigation to at least some of the pastures during this critical period, but the ditches were not in good condition and water application was uneven. Therefore, only modest improvements in the swards were achieved by irrigation. In general, mean monthly rainfall of at least $50 \mathrm{~mm}$ (indicated by the horizontal dashed line in Figure 1) maintained FCS not lower than 5.5. Three peaks of rainfall (monthly means exceeding $120 \mathrm{~mm}$ ) were associated with the highest FCS).

Unfortunately, the stands of leucaena declined sharply in two of the four areas containing them, because of poor drainage and waterlogging. As a result, too little leucaena was left to contribute much toward improving grazing conditions during periods of drought (Figure 1). One objective of this experiment was thereby forfeited.

Mean daily LW gain per grazing cycle by all animals (dry cows and heifers) of the two treatments are shown in Figure 2. These curves are also based on rolling 2-cycle means. Even with the use of this computational device to dampen short-term fluctuations, there is still much rising and falling of both curves that is not easy to explain, as it does not follow the rainfall and FCS patterns. The lack of a preweighing fast may have contributed to unexplained variation in LW. As a rule of thumb, daily gains of less than $0.5 \mathrm{~kg}$ can be considered marginal to inadequate for growing heifers and dry cows repleting body reserves; 0.5 to $0.7 \mathrm{~kg}$ is satisfactory; and above $0.7 \mathrm{~kg}$ is generally not sustainable for long periods in this type of system. Numerous examples of all of these levels of performance are evident, during the first 24 grazing cy-

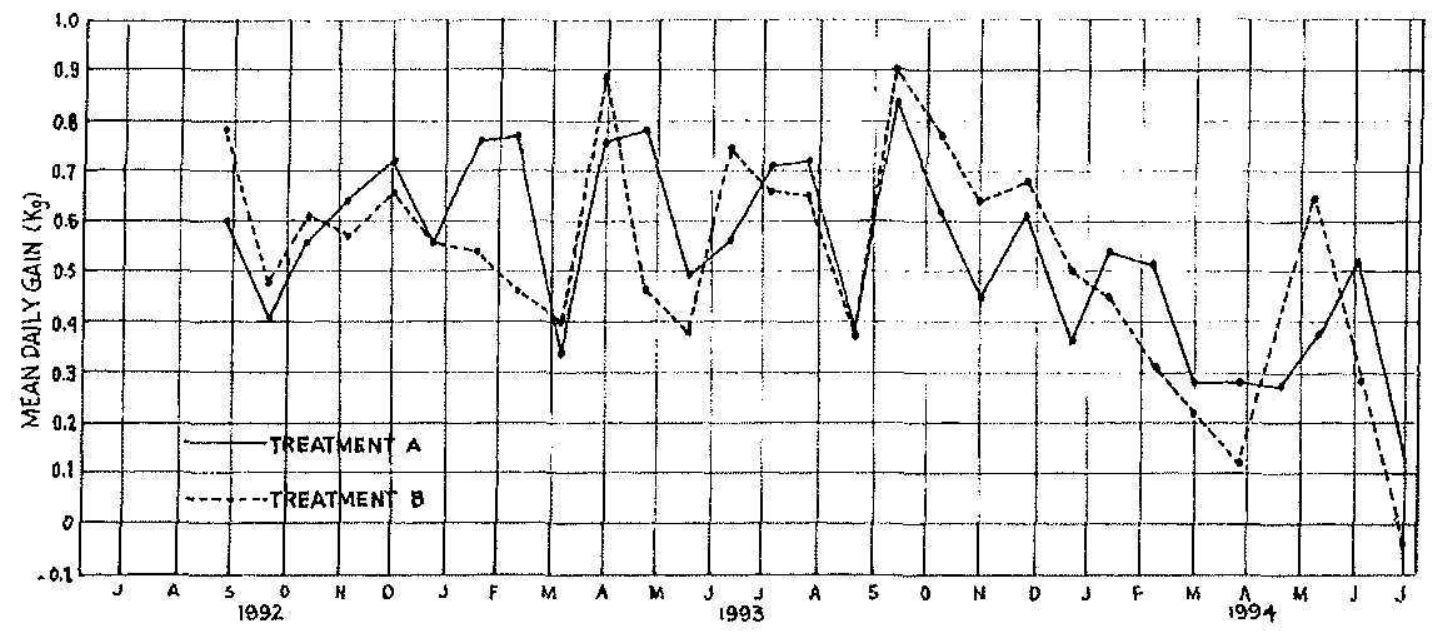

Figure 2. Two cycle rolling means of daily live weight gain for each treatment during the experiment. 
cles, when pasture conditions remained reasonably good. Thereafter, $\mathrm{LW}$ gains were inadequate in five of the last six grazing cycles during prolonged drought.

Data for comparison from the first 19 mo of experimentation include 98 dry cows altogether (Table 1 ). In treatment A the number was less, but the mean length of observation per animal was greater than in $B$. Mean initial and final LW of the cows in A and B were 575 vs. $594 \mathrm{~kg}$ and 647 vs. $659 \mathrm{~kg}$, the differences between treatments not being significant $(P>0.05)$. Variability within-treatment, as indicated by the standard deviation (SD), was nearly alike in both cases. Rate of LW increment in general was quite satisfactory throughout this period of experimentation ( 0.69 vs. $0.67 \mathrm{~kg} /$ day in $\mathrm{A}$ and $\mathrm{B}$, respectively).

The mean initial BCS of treatment $\mathrm{A}$ and $\mathrm{B}$ dry cows during the first 19 mo was 3.03 and 3.11 while the final BCS was 3.45 in both groups, with little difference in within-treatment variability. The increase in $\mathrm{BCS}$ was 0.42 and 0.35 in treatments $\mathrm{A}$ and $\mathrm{B}(\mathrm{P}>0.05)$. Adjusted to $100 \mathrm{~d}$, which constitutes a dry period longer than optimal, but still satisfactory. the mean increase in BCS would be 0.40 and 0.34 in A and B, respectively. The common final $\mathrm{BCS}(3.45)$ was within the range of 3.25 to 3.75 recommended by Sniffen and Ferguson (1991) in cows approaching parturition.

In these data, calculation of the LW increase equivalent to a unit in crease of BCS gives unreasonably high values of 171 and $186 \mathrm{~kg}$ in treatments A and R. By contrast, Wright and Russell (1984) estimated that a LW gain of $110 \mathrm{~kg}$ in nonlactating cows corresponds to a unitary $\mathrm{BCS}$ increase on a scale of 1 to 4 . The equivalent value adjusted to a 1 to 5 scale would be $81 \mathrm{~kg}$. Otto et al. (1991) obtained a similar estimate of $79 \mathrm{~kg} \mathrm{LW}$ per unit of BCS increase in their study on body composition of culled Holstein cows. The present overestimates of LW-BCS equivalency can be ascribed to the use of only a fraction of a point change in $\mathrm{BCS}$ and a long extrapolation. Another contributing factor was perhaps too conservative judging of BCS change, due to lack of familiarity with $\mathrm{BCS}$ higher than 3.5. All scores were assigned by a single judge.

Of the dry cows that were subjected to treatments $A$ and $B$ during the grazing phase and went on to calf, mean LW was 656 and $672 \mathrm{~kg}$ at the prepartum weighing nearest to calving, 604 and $617 \mathrm{~kg}$ at calving, and 555 and $566 \mathrm{~kg}$ at six weeks after calving (Table 2). Maternal LW loss at parturition for cows of the two respective groups was 53 and 55 $\mathrm{kg} ; 37.2$ and $35.4 \mathrm{~kg}$ of which represented birthweight of the offspring. The LW loss of the cows from calving to six weeks postpartum was 47 and $46 \mathrm{~kg}$. Total LW loss from prepartum to six weeks after calving: slightly exceeded $100 \mathrm{~kg}$ in both groups. Over this same interval, BCS declined by 0.76 and 0.71 point, respectively. Mean BCS of both groups 
TABLE 2.-Mean post-treatment changes in live weight and body condition score from prepartum to six weeks postparlum.

\begin{tabular}{lrr}
\hline & Treatment A & Treatment B \\
\hline Live weight (kg) & & \\
Prepartum & $656+70(63)^{\prime}$ & $672+69(76)$ \\
Postpartum & $604+69(63)$ & $617+66(76)$ \\
Loss at calving & $53+21(63)$ & $55+25(76)$ \\
Six weeks postpartum & $555+58(60)$ & $566+60(68)$ \\
Loss from calving to 6 wk postpartum & $47+33(59)$ & $46+33(68)$ \\
Loss from prepartum to 6 wk postpartum & $103+36(60)$ & $102+40(68)$ \\
Body condition score (1-5) & & \\
Prepartum & $331+0.34(62)$ & $3.30+0.33(76)$ \\
Six weeks postpartum & $2.55+0.45(60)$ & $2.58+0.43(68)$ \\
Loss from prepartum to 6 wk postpartum & $0.76+0.39(60)$ & $0.71+0.41(68)$ \\
Birth weight of offspring $(\mathrm{kg})$ & $37.2+6.3(62)$ & $35.4+6.8(76)$ \\
\hline
\end{tabular}

'Standard deviation, number of observations in parenthesis.

${ }^{2} \mathrm{BCS}$ : See footnote of Table 1 .

was slightly above 2.5 at six weeks postpartum. Sniffen and Ferguson (1991) recommend a score of 2.5 as the minimum that a well-managed dairy cow should reach during early lactation, when a negative energy balance is expected. No residual effects of the treatments applied during the grazing phase of the dry period were detected $(P>0.05)$ in any of these transitional variables.

Data were obtained on 122 standard 305-d lactations of previously dry cows subjected to treatments $A$ and $B$. The general mean was 4,350 $\mathrm{kg}$ of milk (Table 3). Fifty-six group A cows had a mean production of $4,276 \mathrm{~kg} ; 66$ cows of group B, a mean of $4,450 \mathrm{~kg}$. Mean milk fat percentage differed by only 0.02 between groups $A$ and $B$, whereas mean protein percentage was the same for both (Table 3 ). Within-group variability in these lactational criteria was somewhat greater for B than for A.

To examine the effect of the prepartum BCS on subsequent milk yield, data from both groups were combined and the animals were grouped according to BCS class (Table 3). Lactational yield was least $(4,013 \mathrm{~kg})$ in cows of lowest BCS $(<3.0)$, and increased successively by 98,256 and $260 \mathrm{~kg}$ of milk in cows of scores $3.0,3.25$ and 3.5 before declining again by $177 \mathrm{~kg}$ in those of BCS >3.5. This trend in BCS approached significance $(\mathrm{P}<0.10)$. Of these five BCS classes, the middle three included data from at least 25 lactations, whereas the classes at both ends of this distribution included only 12 and 13 lactations. Results obtained with cows of classes $3.0,3.25$ and 3.5 permit affirming, 
TABLE 3.-Milk production and milk composition in standard 305-day lactations and relation between prepartum body condition score and produclion.

\begin{tabular}{|c|c|c|c|c|}
\hline & & Treatment $A$ & Treatment B & Combined data \\
\hline \multicolumn{2}{|c|}{ Number of lactations } & 56 & 66 & 122 \\
\hline \multicolumn{2}{|c|}{ Milk production $(\mathrm{kg})$} & $4,276+883$ & $4,450+1,048$ & 4,350 \\
\hline \multicolumn{2}{|c|}{ Milk fat content $(\%)$} & $3.30+0.40$ & $3.32+0.50$ & 3.31 \\
\hline \multicolumn{2}{|c|}{ Milk protein content (\%) } & $3.15+0.15$ & $3.15+0.19$ & 3.15 \\
\hline \multirow[b]{2}{*}{ Prepartum BCS } & \multirow{2}{*}{$\begin{array}{l}\text { Number } \\
\text { of lactations }\end{array}$} & \multicolumn{2}{|c|}{ Milk production ( $\mathrm{kg}$ ) } & Difference \\
\hline & & Mean and SD & C.V. ${ }^{1}$ & group (kg) \\
\hline$<3.0$ & 12 & $4,013+734$ & 18.3 & -98 \\
\hline 3.0 & 29 & $4,111+874$ & 21.3 & 0 \\
\hline 3.25 & 25 & $4,367+972$ & 22.3 & 256 \\
\hline 3.5 & 43 & $4,627+884$ & 19.1 & 516 \\
\hline$>3.5$ & 13 & $4,450+1,470$ & 33.0 & 339 \\
\hline
\end{tabular}

'Coefficient of variation.

on the basis of a reasonable volume of data, that over the BCS interval in question, each increase of 0.25 point enabled the cows to produce about $258 \mathrm{~kg}$ more milk per standard lactation. A change from 3.0 to 3.5 resulted in an increased milk yield of over $500 \mathrm{~kg}$. The effect of BCS $>3.5$ requires further study, in view of the small number of observations and the large within-class variability at this level of body condition in the present data.

The relationship between $\mathrm{BCS}$ at drying off and at parturition with subsequent milk yield may be complicated by a number of factors. Indeed, some of the published results are difficult to interpret. In their pioneering study, Wildman et al. (1982) found in 30 herds in Virginia, a greater proportion of overconditioned than of underconditioned cows at drying off. In general, BCS remained constant during the dry period. Subsequently, lactating cows corresponding to categories of increasing efficiency of milk production (defined as $4 \%$ fat-corrected-milk/kg $\mathrm{LW}^{0.75}$ ) of $<0.16,0.16$ to 0.22 and $>0.22$ had decreasing mean BCS of 3.3, 2.8 , and 2.5 , respectively. The reverse was true of persistency of lactation, i.e, more persistent cows showed higher BCS.

Ruegg and Milton (1995) judged, on a 1 to 5 scale by the method of Edmonson et al. (1989), BCS of Holstein cows in Canada of a production level almost double that of the present study. BCS at calving (3.23 mean) had no effect on either peak or 305-d lactational production. After reaching minimum values of 2.25 to 2.5 at 50 to $90 \mathrm{~d}$ postpartum, the cows regained 
0.53 point during the rest of lactation. This situation of moderate body condition and lack of a large loss of condition in early lactation, gave good results in reproductive performance and herd health, as well as milk yield.

In a large, high-producing Holstein herd in Michigan, Domecqu et al. (1997) observed that a 1-point increase in BCS during the dry period (also determined according to Edmonson et al., 1989) was associated with a $545 \mathrm{~kg}$ increase in milk yield during the first $120 \mathrm{~d}$ of lactation. However, each additional point of BCS at drying off was associated with $300 \mathrm{~kg}$ less milk output in $120 \mathrm{~d}$. A mean BCS at parturition of 2.66 was compatible with high production. Hady and Tinguely (1996) in Idaho examined data from numerous herds and observed a general trend toward higher milk output with higher BCS at the late dry cow stage; however, variability was great, and significant differences were not found. Holter et al. (1990) reported that cows underconditioned at calving ( $80 \%$ of normal according to a BCS scale of 1 to 9 ) mobilized less body fat in the first trimester of lactation, which depressed milk fat percentage without affecting feed intake or milk yield. Under New Zealand conditions, Thomson et al. (1997) found a positive effect of concentrate feeding (versus pasture only), but no effect of BCS at calving on milk yield or composition.

The foregoing research results from temperate regions may have limited applicability to conditions of tropical dairying. It seems logical that higher BCS at calving should benefit milk yield more in herds in which feeding of lactating cows is inadequate to enable them to achieve their full productive potential. Lasso et al. (1982) studied the effects of BCS at calving on a scale of 1 to 6 , in multiparous Holstein cows in the humid tropics of Mexico, and calculated by regression an increase of $211 \mathrm{~L}$ in lactational milk yield for each 1 point increment in BCS. Cows scoring 6 had the highest mean yield of $3,387 \mathrm{~L}$.

In a recent Cuban study, Reyes et al. (1998) fed multiparous Holstein cows, of mean initial LW $508 \mathrm{~kg}$, at three levels, resulting in daily $\mathrm{LW}$ gains of $<0.3,0.3$ to 0.5 , and $>0.5 \mathrm{~kg}$, during the last 50 to $60 \mathrm{~d}$ of gestation. Mean daily milk yields during the first $8 \mathrm{wk}$ of lactation were $14.51,17.55$, and $20.22 \mathrm{~kg}$, respectively. These authors did not consider $\mathrm{BCS}$, but concluded that these marked differences in production were due to differences in body reserves at calving. This mechanism, whereby body reserves compensate in part for a suboptimal input of dietary energy during lactation, likely also applies to the Lajas herd, in which the forage fed is often not of high quality and milk production is below the genetic potential of the cows.

Table 4 presents subsequent reproductive data from 138 cows formerly subjected to the two treatments. Four categories of performance are defined: (1) the desired situation of cows that conceived again not 
TABLE 4.-Mean post-treatment reproductive performance by cows grouped into four categories of efficiency.

\begin{tabular}{|c|c|c|c|c|}
\hline & $\begin{array}{l}\text { Number } \\
\text { of cows }\end{array}$ & $\begin{array}{l}\text { Percentage } \\
\text { of all cows }\end{array}$ & $\begin{array}{c}\text { Number of } \\
\text { inseminations }\end{array}$ & $\begin{array}{l}\text { Days from } \\
\text { calving to } \\
\text { conception }\end{array}$ \\
\hline \multicolumn{5}{|c|}{ Treatment A } \\
\hline Pregnant again on time ${ }^{1}$ & 24 & 38 & 1.83 & 96.5 \\
\hline Pregnant again tardily ${ }^{2}$ & 26 & 41 & 5.08 & 278 \\
\hline Inseminated unsuccessfully & 12 & 19 & 7.75 & - \\
\hline Not reinseminated & 1 & 2 & - & - \\
\hline Total: & 63 & 100 & - & - \\
\hline \multicolumn{5}{|c|}{ Treatment B } \\
\hline Pregnant again on time & 22 & 29 & 1.55 & 84 \\
\hline Pregnant again tardily & 33 & 44 & 4.73 & 252 \\
\hline Inseminated unsuccessfully & 10 & 13 & 7.60 & - \\
\hline Not reinseminated & 10 & 13 & - & - \\
\hline Total: & 75 & 99 & - & - \\
\hline \multicolumn{5}{|c|}{ Combined Data } \\
\hline Pregnant again on time & 46 & 33 & 1.70 & 90.5 \\
\hline Pregnant again tardily & 59 & 43 & 4.88 & 264 \\
\hline Inseminated unsuccessfully & 22 & 16 & 7.68 & - \\
\hline Not reinseminated & 11 & 8 & - & - \\
\hline Total: & 138 & 100 & - & - \\
\hline
\end{tabular}

'Conceived not more than $150 \mathrm{~d}$ postpartum.

${ }^{2}$ Conceived more than $150 \mathrm{~d}$ postpartum.

more than $150 \mathrm{~d}$ postpartum and required not more than three services; (2) those that conceived again, but with an interval greater than $150 \mathrm{~d}$; (3) those that were reinseminated, but failed to conceive; and (4) those designated for culling that were not reinseminated. Thirty-eight and $29 \%$ of the cows of groups A and B were in the first category; they required 1.83 and 1.55 services to conceive, and had calving-to-conception intervals of 96.5 and 84 days, respectively. Cows in the second category represented $41 \%$ and $44 \%$ of the total of groups $\mathrm{A}$ and B and required 5.08 and 4.73 services to conceive. Their interval from calving until conception was 278 and 252 days, respectively. The combination of cows that were either inseminated unsuccessfully or not reinseminated (categories 3 and 4) constituted $21 \%$ and $26 \%$ of groups A and B, respectively. Only in category 4 did the proportion of cows differ $(\mathrm{P}<0.05)$ between groups ( $2 \%$ vs. $13 \%$ ). Overall, there is insufficient evidence to ascribe an advantage in reproductive efficiency to one previous treatment over the other. 
Upon combining data from both groups, the animals with satisfactory reproductive performance constituted one-third (33\%); those that conceived again after a long delay were $43 \%$; those eliminated from the herd without another calving, for breeding and/or other reasons, constituted nearly one-fourth $(24 \%)$ of the total (Table 4). The cows of category 1 required a mean of 1.7 services, conceived $90.5 \mathrm{~d}$ after calving, and calved again in $369.8 \mathrm{~d}$.

In these data there was no evidence of a beneficial effect of higher prepartum BCS on reproductive efficiency. Cows of categories 1 through 4 in reproduction showed mean BCS at this stage as follows: group A, 3.27, 3.34, 3.29 and 3.5 (one lone cow); group B, 3.26, 3.27, 3.42 and 3.30 ; combined groups, 3.27, 3.30, 3.35, and 3.32, respectively. Markusfeld et al. (1997) observed that Israeli Holstein cows in commercial herds with a higher BCS at calving were less prone to anestrus, but did not have a higher conception rate at first service than lower BCS cows. In another study Hegazy et al. (1997) confirmed the shorter in. terval from calving to first heat in cows of higher BCS, and also found a favorable effect on the number of services per conception. In the $\mathrm{Cu}$ ban work previously cited, Reyes et al. (1998) noted significant tendencies toward fewer services per conception (3.11, 2.64 and 1.81); and shorter intervals from calving to first service (65.3, 55.2 and 50.7 d) and to conception (146.8, 119.5 and $104.2 \mathrm{~d}$ ) across the categories of increasing rate of prepartum LW gain, $<0.3,0.3$ to 0.5 , and $>0.5 \mathrm{~kg}$.

In the present study the values of $\mathrm{BCS}$ at $6 \mathrm{wk}$ postpartum corresponding to categories 1,2 and 3 of reproductive performance were: group A, 2.62, 2.60 and 2.29; group B, 2.61, 2.58 and 2.55. At this point there were only four observations in category 4 of group $B$ and none of $A$. Means of the combined data were 2.62, 2.59,2.44, and 2.31 BCS for the four respective reproductive categories. Only a very slight trend can be seen toward lower BCS in those cows that did not become pregnant again (categories 3 and 4), and scarcely any difference between the satisfactorily performing and delayed breeder cows (categories 1 and 2). Perhaps an effect of BCS on reproduction of the latter two categories would have been detected if scoring had been done again at a later postpartum stage. Unpublished observations in this herd subsequent to the present experiment have shown that BCS of a high proportion of cows continues to decline beyond 6 wk postpartum and often recovers little until near the end of lactation. High milk production and energy deficiency in early lactation are known to be associated with delayed rebreeding (Butler and Smith, 1989; Staple et al., 1990). Hegazy et al. (1997) concluded that reduced fertility in high-producing cows is not a direct result of enhanced milk secretion, but is due to loss of LW and BCS. If this is so, then cows regaining $\mathrm{BCS}$ should be more fertile than those remaining in low BCS. 
Important conclusions that can be drawn from these results are that the treatments applied during the grazing phase of the dry period, in terms of stocking rate, pasture conditions and supplemental feeding, enabled the dry cows to adequately replete their body reserves in preparation for calving and lactation, except during the final months of prolonged drought. A BCS at calving of 3.5 was required for highest milk production over the lactation, but no effects of body condition on reproductive performance were detected under the conditions of this experiment.

\section{LITERATURE CITED}

Butler, W. R. and R. D. Smith, 1989. Interrelationships between energy balance and postpartum reproductive function in dairy cattle. J. Dairy Sci. 72:767-783.

Domecqu, J. J., A. L. Skidmore, J. W. Loyd and J. B. Kaneene, 1997. Relationship between body condition scores and milk yield in a large daixy herd of high yielding Holstein cows. J. Dairy Sci. 80:101-112

Edmonson, A. J, I. J. Lean, L. D. Weaver, T. Farver and G. Webster, 1989. Body condition scoring chart of Holstein dairy cows. J. Dairy Sci. 72:68-78.

Frank, T. J., L. H. Shultz and A. R. Hardie, 1980. Effect of dry period overconditioning on subsequent metabolic disorders and performance of dairy cows. J. Dairy Sci. 63: 1080-1090.

Gearhart, M. A., C. R. Curtis, H. N. Erb, R. D. Smith, C. J. Sniffen, L. E. Chase and M. D. Cooper, 1990. Re1ationship of changes in condition score to cow health in Holstein. J. Dairy Sci. 73:3132-3140.

Goering, H. K. and P. J. Van Soest, 1970. Forage fiber analyses (apparatus, reagents, procedures and some applications). Agric. Handbook 379. ARS, USDA, Washington, D.C.

Hady, D. J. and L. L. Tinguely, 1996. Impact of late dry cow body condition on second test milk in a large western dairy. Agri-Practice 17(1):6-11. From Dairy Sci. Abst. 58(7):509, 1996.

Hegazy, M. A., S. A. Essawi and A. H. Youssef, 1997. Relationship between body condition, milk yield and reproductive performance of dairy cows. Vet. Med. J. Giza 45(2): 147-154. From Dairy Sci. Abst. 60(3):167, 1998.

Holter, J. B., M. J. Slotnick, H. H. Hayes, C. K. Bozak, W. E. Urban, Jr. and M. L. McGilliard, 1990. Effect of prepartum dietary energy on condition score, postpartum energy, nitrogen partitions and lactation production responses $J$. Dairy Sci. 73:3502-3511.

Lasso, T. G., F. N. Meléndez and J. Scoffeld, 1982. El grado de condición de vacas Holstein y la relación con su producción y fertilidad en el trópico humedo. Prod. Anim. Thop. 7:208-214.

Markusfeld, O., N. Galon and E. Ezra, 1997. Body condition score, health, yield and fertility in dairy cows. Vet. Rec. 141(3);67-72.

Mejía, R., P. F. Randel and E. Riquelme-Villagxán, 1993. Crecimiento de novillas pastoreando gramíneas de secano y con acceso limitado a Leucaena leucocephala, melaza/urea y/o concentrado. Arch. Latinoam. Prod. Anim. 1:29-38.

NRC, 1988. Nutrient Requirements of Dairy Cattle (6th Rev. Ed., update 1989). National Academy Press, Washington.

Otto, K. L., J. D. Ferguson, D. G. Fox and C. J. Sniffen, 1991. Relationship between body condition score and composition of ninth to eleventh rib tissue in Holstein dairy cows. J. Dairy Sci. 74:852-859. 
Reyes, J., R. García and H. Jordán, 1998. Effect of pre-calving live weight gain on postcalving performance of commercial Holstein cows. Cuban J. Agric. Sci. 32:239-243.

Ruegg, P. L. and R. L. Milton, 1995. Body condition scores of Holstein cows in Prince Edward Island, Canada: relationships with yield, reproductive performance, and disease. J. Dairy Sci, 78:552-564.

Snedecor, G. W., 1956. Statistical Methods (5th Ed.), Iowa State College Press, Ames, IA.

Sniffen, C. J. and J. D. Ferguson, 1991. Body condition scoring guide. Church \& Dwight Coi., Princeton, NJ.

Staples, C. R., W. W. Thatcher and J. H. Clark, 1990. Relationship between ovarian activity and energy status during the early postpartum period of high producing cows. J. Dairy Sci. 73:938-947.

Thomson, N. A., C. R. Mudford and C. W. Holmes, 1997. Milk solid response in early lactation to condition score at calving and concentrate feeding. Proc. N. Z. Soc. Anim. Prod. 57:157. From Dairy Sci. Abst. 60(2):622, 1998.

Wildman, E. E., G. M. Jones, P. E. Wagner, R. L. Boman, H. F. Troutt, Jr. and T. N. Lesh, 1982. A dairy cow body condition scoring system and its relationship to selected production characteristics. J. Dairy Sci. 65:495-501.

Wright, I. A and A. J. F. Rusell, 1984. Partition of fat, body composition, and body condition scoring in mature cows. Anim. Prod. 38:23. 